\title{
FLIPPED CLASSROOM: SEKOLAH TANPA PEKERJAAN RUMAH
}

\author{
Flipped Classroom: \\ School Without Homework
}

\author{
Mujiono \\ Universitas Terbuka \\ Jl. Pd. Cabe Raya, Pd. Cabe Udik, Pamulang, Kota Tangerang Selatan, \\ Banten, Indonesia \\ mujiono.ut@ecampus.ut.ac.id
}

Diterima:

10 September 2018,

Direvisi:

15 Januari 2019,

Disetujui:

28 Mei 2021

\begin{abstract}
ABSTRAK: Pekerjaan rumah yang dibawa pulang para siswa selama ini masih berupa soal-soal akademik. Sesampainya di rumah, tidak sedikit siswa merasa kesulitan mengerjakan pekerjaan rumah tersebut. Minimnya waktu belajar di sekolah, keadaan orang tua yang kadang disibukkan dengan pekerjaan, dan ketidakpahaman siswa atas konten atau materi pelajaran menjadi persoalan-persoalan yang dihadapi siswa. Meskipun pemerintah menganjurkan untuk tidak membebankan pekerjaan rumah kepada siswa, kenyataan di lapangan guruguru masih memberikan soal-soal akademik sebagai tugas yang harus dikerjakan siswa selama berada di rumah. Sudah seharusnya guru-guru mempertimbangkan bahwa setiap siswa merupakan pribadi yang unik dengan beragam karakter dan kemampuan. Masing-masing siswa memiliki kecepatan belajar yang berbeda-beda, sehingga tidak cukup bila hanya mengandalkan waktu belajar di dalam kelas. Perlu kiranya guru-guru mengembangkan dan menggunakan model-model pembelajaran yang inovatif, untuk mengakomodasi beragam karakter dan kemampuan masing-masing siswa. Tujuan penelitian ini adalah untuk memberikan alternatif model pembelajaran yang tidak membebankan pekerjaan rumah kepada siswa. Melalui model Flipped Classroom, pembelajaran dilakukan dengan cara membalik apa yang secara tradisional dikerjakan di dalam kelas, diubah untuk dikerjakan di rumah, dan yang secara tradisional dikerjakan di rumah sebagai pekerjaan rumah diubah untuk diselesaikan di dalam kelas.
\end{abstract}

Kata Kunci: Flipped Classroom, sekolah tanpa pekerjaan rumah, pekerjaan rumah.

ABSTRACT: Nowadays, homework given to the students are still in the form of academic matters. At home, many students find it is difficult to do the homework. Their lack of time to learn, their parents who are busy with their works, and their limited understanding on the learning material have become the problems for them. Even though the government encourages 
the teachers not to give homework to the students, in reality many teachers still give their students homework in the form of academic matters. The teachers should have now considered that each student has unique personality with their own characteristics and capacity. They have different learning speed so that it is not enough for most of them to just rely on the learning time in the class. The teachers need to develop and use innovative learning models to accommodate various characteristics and capacity of the students. The objective of this research is to give learning model alternative that is not felt as burden of homework by the students. Through the model of Flipped Classroom, the learning is carried out in its reverse: what are usually done in the classroom are changed should be done at home; and what are traditionally done at home are changed should be done in the classroom.

Keywords: Flipped Classroom, school with out homework, homework.

\section{PENDAHULUAN}

Pengajaran yang dilakukan kebanyakan guru di sekolah saat ini masih bersifat tradisional (Mujiono, 2017). Tegasnya, sosok guru masih mendominasi proses pembelajaran yang ada di dalam kelas (Nadia \& Hadi, 2014). Para siswa hanya dituntut untuk duduk dan diam di dalam kelas serta mendengarkan informasi/materi apa saja yang disampaikan oleh guru. Pembelajaran satu arah yang menjadikan guru sebagai sumber informasi utama dan siswa berperan pasif adalah model pembelajaran zaman dulu dan tidak lagi sesuai dengan tuntutan perkembangan zaman (Zeki \& Guneyli, 2014). Meskipun kurikulum terbaru memberikan pendekatan kepada siswa untuk memiliki peran lebih aktif, kenyataannya kebanyakan guru masih memakai cara-cara pengajaran tradisional. Langkah-langkah pengajaran secara tradisional umumnya dimulai dari menjelaskan materi, memberikan latihan, dan diakhiri dengan pekerjaan rumah (Widiana \& Jampel, 2016).

Pengajaran yang efektif tidaklah sesederhana hanya sebatas memindahkan pengetahuan dariseseorangkepada orang lain. Pengetahuan tentang bagaimana memindahkan informasi dan keteramilan setidaknya sama penting dengan pengetahuan tentang informasi dan keterampilan itu sendiri (Slavin, 2011). Pengajaran yang efektif tidak terjadi secara kebetulan, perlu melibatkan perencanaan dan persiapan yang matang.Diakui secara luas bahwa perencanaan adalah bagian terpenting dari proses pengajaran (Bassett, dkk., 2013). Guru harus memperhitungkan perbedaan dan keragaman siswa dalam perencanaan pengajaran yang akan mereka lakukan (Black, dkk., 2019).

Untuk dapat memahami materi pelajaran tertentu, setiap siswa membutuhkan waktu belajar yang berbeda-beda (Mujiono, 2017). Ada yang dengan membaca atau belajar satu kali kemudian mereka bisa memahami, tetapi ada pula yang harus membaca atau belajar beberapa kali supaya mereka bisa mengerti materi yang dipelajari. Hal semacam ini kadang kala menjadi sebuah permasalahan yang dihadapi oleh guru-guru di kelas. Sering ditemui siswa-lambat dalam belajar dan membutuhkan alokasi waktu belajar yang lebih banyak daripada temannya. 
Mujiono: Flipped Classroom. Sekolah Tanpa Pekerjaan Rumah

Masing-masing siswa terlahir dengan tingkat kemampuan yang berbeda. Tugas guru adalah membantu para siswa untuk bisa mengembangkan kemampuan dan bakat yang dimilikinya (Mujiono, 2017). Kebanyakan guru hanya terpaku pada materi yang harus dihabiskan pada alokasi waktu tertentu, tanpa memikirkan apakah para siswa memahami materi tersebut ataukah tidak. Seolah-olah tugas guru hanya sekedar menyampaikan materi pelajaran. Mereka lupa bahwa membantu siswa agar bisa memahami materi pelajaran, atau bahasa sederhananya memfasilitasi belajar siswa, merupakan tugas yang tidak boleh diabaikan.

Terbatasnya waktu yang disediakan sekolah dalam proses pengajaran di kelas menjadi kendala utama bagi guru. Dalam beberapa jam pelajaran, guru dituntut harus menyampaikan materi yang sudah ditentukan sebelumnya. Pembelajaran di kelas habis digunakan guru untuk menyampaikan materi, dan pada akhirnya siswa tidak memiliki banyak waktu untuk menyampaikan pertanyaan tentang materi yang belum mereka pahami. Sepulang dari sekolah, siswa mendapatkan pekerjaan rumah (PR) berupa tugas-tugas akademik yang harus dikerjakan selama di rumah. Terbatasnya pemahaman yang didapatkan dari pengajaran guru di kelas, siswa pun pada akhirnya kesulitan mengerjakan PR tersebut. Ketika mendapat kesulitan seperti ini, kebanyakan siswa bingung mencari bantuan, karena tidak semua orang tua mampu atau bisa membantu siswa mengerjakan PR. Beberapa dari mereka memiliki orang tua yang berpendidikan tinggi dan dapat membantu mereka mengerjakan $\mathrm{PR}$, sementara yang lain memiliki orang tua yang tidak memiliki pengetahuan dalam konten/materi pelajaran dan tidak dapat membantu mereka untuk mengerjakan PR (Schmidt \& Ralph, 2016).

Di daerah pedesaan, mayoritas orang tua hanya mengenyam pendidikan tingkat rendah, sedangkan di kota mayoritas orang tua menghabiskan waktunya untuk bekerja. Pada akhirnya, banyak siswa memilih jam belajar tambahan di luar sekolah. Orang tua dengan tingkat perekonomian menengah ke atas dengan mudah memasukkan anakanaknya ke dalam lembaga kursus atau menggunakan jasa guru privat. Tetapi, bagi orang tua yang mengalami kendala perekonomian, tentu akan berpikir dua kali apabila harus memasukkan anak-anaknya ke dalam lembaga kursus ataupun menggunakan jasa guru privat. Hal ini seharusnya menjadi pertimbangan para guru untuk mengelola pembelajaran di sekolah agar proses pengajaran menjadi lebih efektif. Untuk dapat meningkatkan kualitas pendidikan memang tidak sederhana (Darmawan \& Harahap, 2016). Beberapa kondisi perlu diperhatikan untuk memperoleh hasil yang maksimal. Guru sebagai penentu jalannya proses pembelajaran memiliki kewenangan penuh untuk menciptakan kondisi yang ideal bagi para siswanya untuk dapat belajar dengan baik. Mereka perlu memperbarui dan memperbaiki pengajaran dan lingkungan pembelajaran yang dirancang, peran guru dan siswa, serta bahan belajar yang digunakan (Çevikba ${ }^{\circ}$ \& Argün, 2017).

Tanggung jawab guru adalah untuk memfasilitasi dan merancang tindakan yang mengarah pada pencapaian tujuan pembelajaran (Griffiths, 2005). Berbagai cara dapat dilakukan guru untuk bisa merancang dan mempersiapkan proses pembelajaran di dalam kelas. Salah satunya adalah dengan mengembangkan atau menggunakan modelmodel pembelajaran (Mujiono, dkk., 2018). Guru harus mulai berpikir secara profesional dengan mendukung penggunaan model pembelajaran baru (Hubbell \& Goodwin, 2019) yang mampu memberikan pengaruh besar terhadap pengetahuan dan keterampilan siswa.

Meskipun saat ini banyak model pembelajaran yang berkembang, kebanyakan di antaranya masih membebankan pekerjaan rumah kepada siswa. Pekerjaan rumah yang berupa soal-soal akademik merupakan rangkaian kegiatan pada model-model pembelajaran tradisional dan sering kali digunakan guru di sekolah. Untuk itu, sebaiknya guru memberikan perhatian khusus dalam memilah dan memilih model 
pembelajaran yang lebih sesuai dengan karakter dan kebutuhan siswa (Nadia \& Hadi, 2014). Guru merupakan ujung tombak pendidikan, sudah seharusnya selalu berupaya melaksanakan tugas dengan baik. Mereka harus ikhlas dalam melaksanakan tugas mulia tersebut (Sani, 2013). Guru yang kreatif dalam menggunakan model pembelajaran akan mampu mengoptimalkan seluruh potensi siswa (Warsihna, 2013).

Seiring kemajuan siswa di sekolah, pembelajaran menjadi lebih efektif (Krahenbuhl, 2017) karena dari tahun ke tahun para siswa diajarkan tentang bagaimana cara untuk menjadi pembelajar yang hebat. Sekolah yang baik secara proaktif bekerja memfasilitasi keberagaman siswa untuk aktif belajar (Rhim, 2020).

Perlu kiranya membuat kegiatan pendidikan yang lebih efisien tanpa mengesampingkan efektivitas proses pembelajaran. Salah satu cara yang mungkin untuk mencapai tujuan ini adalah reorganisasi pengajaran dan lingkungan pembelajaran dengan model pembelajaran Flipped Classroom (Çevikbaº \& Argün, 2017).

\section{METODA}

Analisis isi (Content Analysis) merupakan metode yang digunakan dalam penelitian ini. Krippendorff (2004) menjelaskan bahwa analisis isi merupakan metode yang didasarkan secara empiris, eksplorasi dalam proses, dan prediksi atau inferensial. Analisis isi mengacu pada tindakan menafsirkan dan menghasilkan kesimpulan selama proses analitis (Drisko \& Maschi, 2015).

Beberapa skema penelitian analisis isi, yakni: (1) Utilizing, dengan mengambil data/ informasi dari beberapa literatur, baik buku maupun artikel jurnal tentang Flipped Classroom; (2) Sampling, dengan memilih dan membatasi data/informasi hanya dari sumber primer (buku dan artikel jurnal) tentang Flipped Classroom; (3) Recording, dengan menjelaskan data/informasi tentang Flipped Classroom secara rinci dan naratif; (4) Reducing, dengan menyediakan data/ informasi tentang Flipped Classroom secara sederhana dan efisien; (5) Inferring, dengan menganalisis data/informasi tentang Flipped Classroom dan mencari makna yang terkandung di dalamnya; dan (6) Naratting, dengan memberikan jawaban atas pertanyaan penelitian berdasarkan hasil kajian data/informasi tentang Flipped Classroom.

Analisis isi dapat digunakan untuk pembahasan mendalam terhadap semua bentuk komunikasi, baik komunikasi dalam bentuk teks, audio maupun visual. Beberapa contoh saluran komunikasi yang biasa digunakan oleh kebanyakan orang di antaranya adalah surat kabar, berita radio, berita televisi dan dokumen dalam bentuk yang lainnya (Jarir \& Khairiah, 2019), sedangkan untuk kalangan akademisi komunikasi wajib yang sering digunakan yakni buku dan artikel jurnal.

Pada penelitian ini, buku teks yang dianalisis adalah buku yang ditulis Bergmann \& Sams (2012) berjudul Flip Your Classroom: Reach Every Student in Every Class Every Day. Buku ini berisi sembilan Chapter, yang kemudian beberapa di antaranya dijadikan pokok bahasan dalam analisis isi, yakni: Pengalaman Bergmann \& Sams membuat model Flipped Classroom; Mengapa harus menggunakan model Flipped Classroom; Bagaimana menerapkan model Flipped Classroom; dan Kasus-kasus yang biasanya terjadi dalam menerapkan Flipped Classroom. Beberapa artikel jurnal yang membahas tentang efektivitas model Flipped Classroom digunakan untuk melengkapi bahan analisis.

Peneliti mencoba menguraikan kesimpulan tentang model pembelajaran Flipped Classroom untuk mengatasi permasalahan terkait kurangnya waktu belajar di sekolah. Siswa yang lambat belajar tidak cukup bila hanya menggunakan waktu yang disediakan sekolah dengan beberapa jam pelajaran selama di kelas. Meniadakan pekerjaan rumah untuk siswa dengan menggunakan model pembelajaran Flipped Classroom, memberikan waktu belajar kepada siswa lebih banyak daripada model pembelajaran secara tradisional. 
Mujiono: Flipped Classroom. Sekolah Tanpa Pekerjaan Rumah

\section{HASIL DAN PEMBAHASAN}

\section{Model Pembelajaran}

Model pembelajaran adalah kerangka konseptual yang dapat digunakan guru sebagai panduan dalam mengajar untuk membantu siswa memperoleh informasi baru (Rahayu, 2015). Umumnya, setiap model pembelajaran memiliki tahapan-tahapan atau langkah-langkah (syntax) yang relatif tetap, berurutan, dan pasti. Tahapan-tahapan tersebut digunakan sebagai pedoman guru untuk menyajikan materi pelajaran. Model pembelajaran dianggap sebagai teori mini yang bersifat mekanis, yakni berjalan secara sistematis seperti mesin (Nadia \& Hadi, 2015).

Model pembelajaran yang baik harus bisa memfasilitasi belajar siswa dan memberikan kesempatan kepada siswa mengonstruksi pengetahuan melalui pengalaman belajar secara mandiri (Isrok'atun \& Tiurlina, 2016). Pemilihan model pembelajaran harus sesuai dengan tujuan pembelajaran yang telah ditetapkan, materi pembelajaran yang akan disampaikan, karakteristik dan kemampuan siswa, kemampuan guru dalam mengelola pembelajaran, serta sumber belajar yang digunakan.

Model pembelajaran mempunyai empat ciri khusus (Darmadi, 2017), yaitu:

1. Rasional teoritis logis

Model pembelajaran mempunyai teori berpikir yang bisa diterima akal. Artinya, para perancang atau pengembang model pembelajaran harus mempertimbangkan bahwa teorinya sesuai dengan kondisi di lapangan.

2. Tujuan pembelajaran

Model pembelajaran mempunyai tujuan yang jelas tentang apa yang akan dicapai, bagaimana siswa belajar dengan baik, dan bagaimana cara memecahkan suatu masalah yang terjadi dalam proses pembelajaran.

3. Tingkah laku mengajar

Model pembelajaran memiliki tingkah laku mengajar yang telah ditetapkan, karena dalam model pembelajaran terdapat langkah (syntax) yang harus dilaksanakan dengan baik oleh seorang guru.

\section{Lingkungan belajar}

Model pembelajaran memiliki lingkungan belajar yang kondusif dan nyaman bagi siswa sehingga suasana belajar dapat menjadi salah satu aspek penunjang untuk bisa mencapai tujuan pembelajaran.

\section{Flipped Classroom}

Flipped Classroom atau membalik kelas pada dasarnya merupakan konsep model pembelajaran dengan membalik proses pembelajaran yang secara tradisional dilakukan di kelas diubah untuk dilakukan di rumah, dan yang secara tradisional dilakukan sebagai pekerjaan rumah diubah untuk diselesaikan di dalam kelas (Bergmann \& Sams, 2012). Pengiriman konten atau materi pelajaran dapat menggunakan berbagai bentuk, misalnya video pembelajaran online, diskusi kolaboratif online, penelitian digital, dan teks bacaan (Suo \& Hou, 2017).

Model Flepped Classroom muncul berawal dari permasalahan yang dikeluhkan para siswa. Ketika di dalam kelas, guru berbicara menyampaikan materi pelajaran dengan terlalu cepat sehingga para siswa tidak sempat mencatat penjelasan yang disampaikan guru. Sepulang dari sekolah, ketika siswa hendak menyelesaikan pekerjaan rumah, mereka kebingungan karena apa yang mereka catat selama di sekolah tidak sesuai dengan tugas yang akan mereka kerjakan. Mereka juga mengalami kesulitan memahami cacatan yang telah mereka buat selama di sekolah. Bergmann \& Sams (2012) sudah menerapkan model ini beberapa tahun dan memberikan kesimpulan bahwa Flipped Classroom dapat mengatasi masalah kebutuhan siswa yang beragam dan memungkinkan guru melakukan pengajaran yang berorientasi kepada siswa, dengan cara memberikan kesempatan dan kebebasan kepada siswa untuk belajar secara mandiri selama berada di rumah.

Ruang kelas, yang menggeser pembelajaran dari model tradisional yang berpusat pada guru menjadi berpusat pada siswa, mengubah peran guru dari dominator kelas menjadi fasilitator pembelajaran siswa. Namun, ini tidak berarti bahwa peran guru 
melemah, sebaliknya, menjadi kuat karena pekerjaan guru tidak hanya mempersiapkan konten pembelajaran sebelum kelas dimulai, tetapi juga untuk merancang dan mengatur kegiatan kelas, yakni: memonitor dan membimbing siswa, serta mengevaluasi kinerja siswa (Suo \& Hou, 2017). Ruang kelas ini mencakup banyak kegiatan seperti pemetaan konsep, brainstorming, kolaboratif, pembelajaran berbasis kasus, pembelajaran kooperatif, permainan peran, simulasi, pembelajaran berbasis proyek, dan peer teaching (Kurihara, 2016).

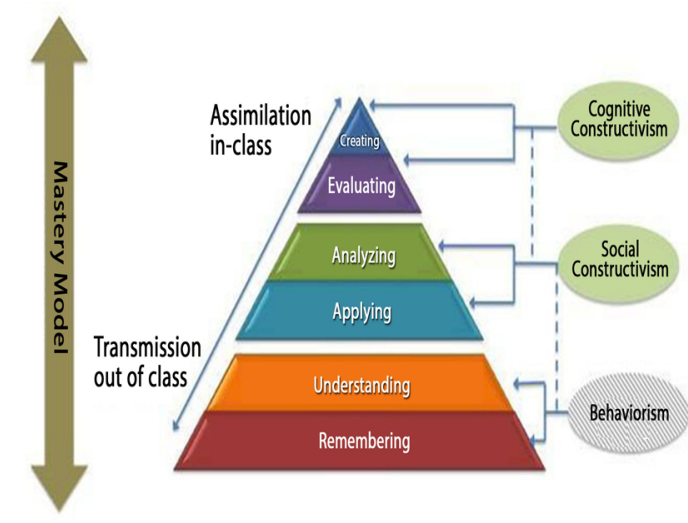

Gambar 1. Synthesis of the Models and Theories Associated with Flipped Learning (Eppard \& Rochdi, 2017).

Studi tentang model Flipped Classroom didasarkan pada teori taksonomi kognitif Bloom yang telah direvisi (Zainuddin \& Haili, 2016). Taksonomi ini menyediakan enam tingkatan dalam kemampuan berpikir. Penjelasannya diatur dari tingkat yang terendah hingga ke tingkat tertinggi:

1. Mengingat: siswa mencoba mengenali dan mengingat informasi yang diterima; siswa juga mencoba memahami konsep dan prinsip dasar dari konten yang dipelajari.

2. Memahami: siswa mencoba untuk menunjukkan tingkat pemahamannya, menafsirkan informasi dan merangkum apa yang telah dipelajari.

3. Menerapkan: siswa mempraktekkan apa yang telah dipelajari atau menerapkan pengetahuan yang dimiliki pada situasi/ kondisi yang sebenarnya.
4. Menganalisis: siswa menggunakan tingkat berpikir kritis dalam memecahkan suatu masalah, berdebat dengan membandingkan jawabannya dengan teman sejawat, dan menghasilkan ringkasan. Siswa mendapatkan pengetahuan dan ide baru setelah menggunakan pemikiran kritis dalam kegiatan debat kelompok. Di level ini, siswa juga dilatih untuk berpikir kreatif.

5. Mengevaluasi: siswa mengevaluasi seluruh proses pembelajaran yang telah dilakukan dan membuat penilaian tentang hasil belajarnya.

6. Menciptakan: siswa dapat merancang, membangun dan menghasilkan sesuatu yang baru dari apa yang telah mereka pelajari (Lorin \& David, 2015).

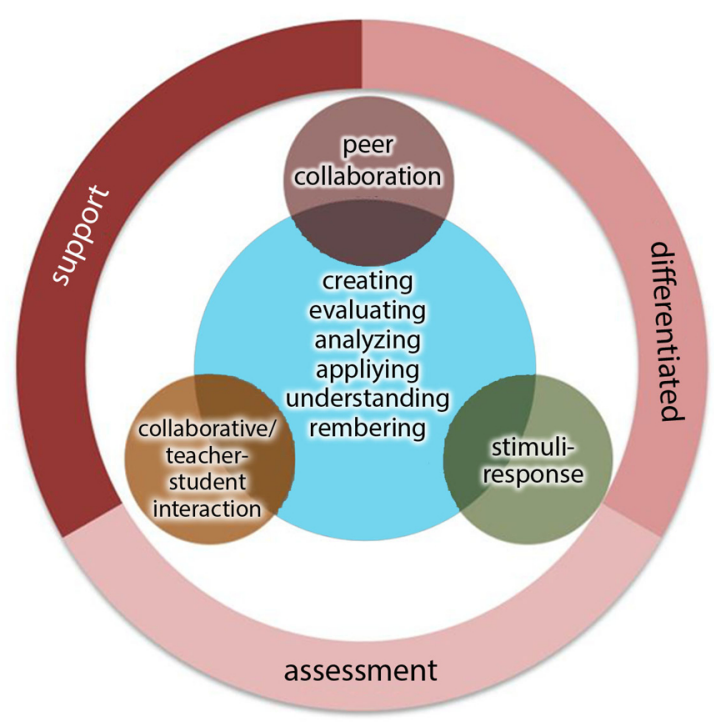

Gambar 2. Synthesis of Learning Processes in Flipped Learning (Eppard \& Rochdi, 2017)

Manfaat dari Flipped Classroom yang berkaitan dengan taksonomi Bloom adalah bahwa siswa secara aktif dibantu dan didukung selama beberapa kegiatan yang membutuhkan pemikiran tingkat tinggi (Eppard \& Rochdi, 2017). Pemikiran tingkat tinggi seperti pemecahan masalah dan kreativitas, digunakan untuk mempersiapkan siswa memasuki dunia kerja ketika mereka sudah lulus dari sekolah (Gomez-Lanier, 2018). Selain itu, kemampuan berpikir tingkat 
tinggi memungkinkan siswa untuk berpikir kritis dan berani mengambil keputusan atas pekerjaan mereka di semua bidang kehidupan (Smith \& Darvas, 2017).

Flipped Classroom memberikan peluang agar interaksi antara guru dengan siswa selama di dalam kelas lebih intensif dan berkualitas. Siswa mengambil sendiri tanggung jawab belajar selama berada di rumah (Ozdamli \& Asiksoy, 2016). Pada akhirnya, siswa dapat belajar dengan kemampuan dan kecepatan masing-masing. Siswa memiliki potensi untuk belajar dalam waktu mereka sendiri dengan jumlah otonomi tertentu dalam hal manajemen waktu (Eppard \& Rochdi, 2017). Konsep semacam itu, memberikan kebebasan kepada siswa untuk menyesuaikan kemampuan dan proses belajar mereka masing-masing sesuai dengan kebutuhannya (Pinnelli \& Fiorucci, 2015).

Pada model pembelajaran Flipped Classroom, proses belajar selama di dalam kelas terjadi ketika siswa berkolaborasi, baik dengan orang dewasa yang lebih terampil maupun teman sejawatnya untuk memecahkan masalah yang berada di luar kemampuannya. Hubungan yang dikembangkan siswa dengan teman sejawat menjadi faktor kunci kesuksesan Flipped Classroom (McCollum, dkk., 2017). Selain meningkatkan kemampuan akademik, hubungan siswa dengan teman sejawat akan mempererat persahabatan mereka. Siswa menjadi lebih perhatian dengan teman, berbicara lebih leluasa dalam diskusi kelompok, dan memperoleh pandangan positif dari upaya kolaboratif. Flipped Classroom memberikan peluang dan kesempatan yang lebih besar kepada para siswa untuk berkolaborasi, masing-masing siswa dapat terhubung dengan teman satu kelompok dalam lingkungan belajar yang lebih berarti (Gomez-Lanier, 2018).

Pada periode tahun 2012, FLN (Flipped Learning Network) melakukan studi tentang guru yang menerapkan Flipped Classroom di SMP dan SMA. Studi ini menunjukkan bahwa 99\% dari guru yang menerapkan Flipped Classroom akan terus menggunakannya, $67 \%$ melaporkan peningkatan dalam kinerja siswa dan $80 \%$ melaporkan peningkatan dalam keterlibatan siswa (Schmidt \& Ralph, 2016).

Setidaknya terdapat lima alasan yang dijadikan pertimbangan guru untuk tetap menggunakan Flipped Classroom, yaitu:

1. meningkatkan keterlibatan siswa;

2. memperkuat keterampilan berbasis kelompok;

3. menawarkan bimbingan kepada siswa yang dipersonalisasi;

4. fokus diskusi kelas; dan

5. memberikan kebebasan (Millard, 2014).

\section{Langkah-langkah Flipped Classroom}

Langkah awal yang harus dilakukan guru dalam menerapkan model Flipped Classroom adalah menyiapkan bahan belajar siswa. Bahan belajar tersebut nantinya akan dipelajari siswa ketika berada di rumah. Guru sebaiknya mempertimbangkan bahan belajar yang sesuai dengan karakter dan kebutuhan siswa. Selain itu, pertimbangan mengenai gaya belajar siswa juga perlu mendapatkan perhatian, agar tujuan pembelajaran yang diinginkan dapat tercapai. Misalnya, siswa dengan gaya belajar auditori memerlukan bahan belajar berbentuk audio/suara, dan siswa dengan gaya belajar visual memerlukan bahan belajar berbentuk visual berupa gambar atau video (Mujiono, 2017).

Salah satu tugas guru yang cukup sulit saat mencoba menerapkan model pembelajaran Flipped Classroom adalah menyiapkan konten atau materi pelajaran yang nantinya digunakan sebagai bahan belajar siswa. Untuk memenuhi karakter dan kebutuhan siswa yang beragam, diperlukan lebih dari satu bentuk atau format bahan belajar untuk siswa. Agar bahan belajar tersebut dapat disajikan dalam berbagai format, salah satu caranya adalah dikemas dalam bentuk digital (Mujiono, 2017). Penggunaan bahan belajar digital lebih menarik perhatian siswa dan memberikan kepuasan dalam belajar, serta membantu mereka mencapai hasil belajar yang lebih baik (Fisher, dkk., 2017).

Tidak semua guru di sekolah mampu memproduksi bahan belajar dalam bentuk digital. Kebanyakan guru di sekolah masih 
didominasi oleh generasi tua, yang pada masanya belum familiar dengan teknologi digital. Untuk mengatasi hal ini, guru dapat menggunakan bahan belajar dari pihak lain. Situs Rumah Belajar yang disediakan Kemendikbud merupakan alternatif bagi guru yang belum/tidak bisa memproduksi sendiri bahan belajar untuk siswa. Beberapa macam konten digital dengan berbagai format telah tersedia di situs tersebut, sehingga guru tinggal memilih bahan belajar untuk siswa yang sesuai dengan materi pelajaran.

Awal pertemuan di dalam kelas, guru memberikan bahan belajar yang akan dipelajari siswa selama berada di rumah. Selama di rumah, tugas siswa hanya belajar dan mencatat materi pelajaran yang belum dimengerti. Kesulitan atau ketidak pahaman siswa terhadap materi yang dipelajari ketika belajar mandiri di rumah, nantinya dibawa ke sekolah dan ditanyakan kepada guru. Di dalam kelas, tugas utama guru adalah sebagai fasilitator (Osman, dkk., 2015). Guru memberikan jawaban dan penjelasan terhadap pertanyaan-pertanyaan yang disampaikan siswa terkait materi pelajaran yang belum dimengerti. Selanjutnya, guru membimbing siswa untuk mengerjakan soalsoal latihan terkait materi pelajaran yang telah dijelaskan. Para guru harus menjadi pengamat yang baik selama proses pembelajaran di kelas. Guru harus bisa menentukan bagian-bagian materi pelajaran mana saja yang dianggap gagal dan perlu dilakukan perbaikan. Guru juga harus menjadi pembimbing yang baik selama pembelajaran di kelas (Akin, 2016).

Diperlukan guru-guru profesional yang benar-benar memahami materi pelajaran agar berhasil menerapkan model Flipped Classroom. Guru perlu memperhatikan pula tentang perbedaan kemampuan kognitif siswa yang erat kaitannya dengan bagaimana cara mereka menganalisis dan mensintesis informasi (Darmawan, dkk., 2017).

Kemampuan untuk berpindah secara mental dari satu topik ke topik lainnya diperlukan, dan pemahaman komprehensif tentang keterkaitan konten sangat penting (Bergmann \& Sams, 2012). Hal ini untuk mempersiapkan seandainya siswa menyampaikan pertanyaan-pertanyaan yang lebih mendalam terkait materi pelajaran.

Apabila terdapat kesulitan atas pertanyaan yang disampaikan siswa, guru harus berani mengakui ketika dia tidak tahu dan harus bersedia mencari jawaban bersama siswa. Guru harus mengambil kesempatan ini untuk menunjukkan apa artinya menjadi pembelajar (guru adalah siswa utama di kelas) (Bergmann \& Sams, 2012). Guru harus menunjukkan kepada siswa apa yang dilakukan orang dewasa ketika mereka tidak tahu jawabannya, mengajari mereka cara berkolaborasi, dan membimbing mereka untuk menemukan jawabannya.

Tidak hanya mempelajari materi atau bahan belajar yang telah diberikan guru, para siswa harus mampu belajar sedemikian rupa untuk mempersiapkan kegiatan individu dan kolaboratif bersama dengan teman kelompok selama proses pembelajaran di dalam kelas. Saat menggunakan model pembelajaran Flipped Classroom, siswa ditugaskan untuk memecahkan masalah dengan memanfaatkan informasi yang telah mereka pelajari melalui konten pembelajaran yang diberikan guru. Untuk menyelesaikan tugastugas ini, siswa bekerja secara individual atau dalam kelompok di bawah pengawasan guru (Eppard \& Rochdi, 2017).

Kegiatan kolaboratif dengan berbagai kelompok memberikan peluang lebih besar kepada siswa untuk dapat menyelesaikan tugas di kelas, dan meningkatkan keterampilan manajemen waktu dalam membangun pemahaman yang lebih besar tentang materi yang sedang dipelajari (Gomez-Lanier, 2018). Sebagian siswa menganggap keterampilan komunikasi mereka mengalami peningkatan melalui kegiatan kolaboratif yang sering dilakukan dalam model pembelajaran Flipped Classroom. Guru harus mendukung dan memfasilitasi diskusi kelompok yang dilakukan oleh siswa dengan petunjukpetunjuk sederhana dan seperlunya, tetapi tidak mendikte arah diskusi (McCollum, dkk., 2017). Hal ini dimaksudkan agar siswa 
Mujiono: Flipped Classroom. Sekolah Tanpa Pekerjaan Rumah

mengambil peran utama dalam proses pembelajaran di dalam kelas.

Proses penilaian dapat dilakukan dengan berbagai macam cara, misalnya melalui studi dokumen yang dilakukan oleh guru ketika mempimpin kelompok dan antarkelompok selama siswa berdiskusi membahas materi pelajaran (Akin, 2016). Guru dapat pula menyiapkan beberapa pertanyaan tentang pengetahuan yang sudah dipelajari siswa. Selanjutnya guru memberikan umpan balik terhadap jawaban yang disampaikan siswa (McCollum, dkk., 2017).

Penilaian sangat perlu dilakukan karena ketika di rumah siswa mungkin tidak benarbenar belajar bila guru tidak memberikan penilaian (Arnold-Garza, 2014). Secara alami siswa ingin memberikan kesan baik kepada guru dan mereka akan merasa malu apabila tidak siap atau tidak dapat menjawab pertanyaan guru (Breimer, dkk., 2016). Penilaian akan merangsang siswa agar mereka benar-benar belajar ketika di rumah. Selain itu, praktik penilaian juga dapat meningkatkan prestasi belajar siswa (Mazur, dkk., 2015).

Secara umum, ada lima komponen utama berikut ini yang harus dilakukan guru sebelum memulai Flipped Classroom.

1. Menetapkan tujuan pembelajaran

Tujuan pembelajaran adalah hasil yang diinginkan untuk setiap siswa. Oleh karena itu, tujuan pembelajaran harus dirancang dengan jelas. Gunakan standar dan kerangka kerja nasional, serta penilaian terbaik untuk menentukan apa yang ingin siswa ketahui dan lakukan.

2. Menyiapkan bahan belajar

Pilih bahan belajar yang akan diberikan kepada siswa sesuai dengan tujuan pembelajaran yang sudah ditentukan. Untuk memberikan hasil terbaik, gunakan beberapa bahan belajar dengan berbagai format, agar siswa nantinya bisa memilih sendiri bahan belajar yang sesuai dengan karakter dan gaya belajarnya.

3. Mendistribusikan bahan belajar

Pastikan setiap siswa memiliki akses untuk mendapatkan bahan belajar yang telah disiapkan. Ada berbagai cara yang dapat dilakukan, misalnya: memposting bahan ajar melalui jejaring sosial, menyimpannya di server sekolah, atau menggandakannya secara manual melalui flashdisk atau CD/ DVD.

4. Membimbing siswa di kelas Jawablah setiap pertanyaan yang disampaikan siswa. Apabila terdapat kesulitan, carilah jawabannya bersamasama dengan siswa. Bimbing juga mereka ketika melakukan diskusi kelompok.

5. Melakukan penilaian

Buat beberapa macam penilaian untuk menunjukkan penguasaan mereka dari setiap tujuan pembelajaran dalam unit studi tertentu. Gunakan beberapa teknik dan instrumen penilaian sesuai dengan masing-masing tujuan pembelajaran.

Selama menggunakan model Flipped Classroom, guru harus memperhatikan empat pilar dalam praktik mengajar mereka (FLN, 2014). Empat pilar tersebut termuat dalam kata F-L-I-P.

1. F (Flexible Environment):

Guru menciptakan ruang belajar yang fleksibel agar para siswa dapat memilih sendiri kapan dan di mana mereka ingin belajar. Selain itu, penggunaan model Flipped Classroom menyediakan ruang belajar yang fleksibel sehingga guru bisa mengakomodasi kebutuhan siswa selama belajar kelompok atau belajar mandiri. Flipped Learning Network (2014) menyebutkan ada tiga indikator yang digunakan:

a. Guru menetapkan ruang dan kerangka waktu yang memungkinkan siswa untuk berinteraksi dan merefleksikan pembelajaran sesuai kebutuhan mereka.

b. Guru terus mengamati dan memantau siswa untuk membuat penyesuaian.

c. Guru memberi siswa berbagai cara untuk mempelajari materi pelajaran dan mendemontrasikan pengetahuan.

2. L (Learning Culture):

Apabila dalam model pembelajaran tradisional, guru adalah sumber informasi utama, sedangkan pada model Flipped Classroom, pembelajaran berpusat pada 
Mujiono: Flipped Classroom. Sekolah Tanpa Pekerjaan Rumah

siswa. Waktu yang tersedia selama di dalam kelas didedikasikan untuk mengekplorasi materi pelajaran secara lebih intensif dan mendalam. Tujuannya agar siswa memiliki peluang belajar yang lebih besar. Selanjutnya, siswa secara aktif terlibat dalam konstruksi pengetahuan karena mereka berpartisipasi dan mengevaluasi pembelajaran dengan cara yang bermakna. Flipped Learning Network (2014) menyebutkan ada dua indikator yang digunakan:

a. Guru memberi siswa kesempatan untuk terlibat dalam kegiatan bermakna tanpa guru menjadi pusatnya.

b. Guru merancang kegiatan dan membuatnya dapat diakses oleh semua siswa melalui diferensiasi dan umpan balik.

3. I (Intentional Content):

Guru berpikir tentang bagaimana cara menggunakan model Flipped Classroom agar dapat membantu siswa dalam mengembangkan pemahaman konseptual dan keterampilan prosedural. Guru menentukan materi apa saja yang harus mereka ajarkan dan materi apa saja yang harus dieksplorasi siswa. Guru menggunakan konten pembelajaran yang menarik untuk memaksimalkan waktu belajar di kelas, mengadopsi metode dan strategi pembelajaran yang berpusat pada siswa, serta menyesuaikan jenjang/ tingkatan kelas dengan materi pelajaran. Flipped Learning Network (2014) menyebutkan ada tiga indikator yang digunakan:

a. Guru memprioritaskan konsep yang digunakan dalam pembelajaran langsung untuk digunakan secara individu oleh siswa.

b. Guru membuat serta menyusun konten pembelajaran yang relevan (biasanya video) untuk siswa.

c. Guru membedakan agar konten pembelajaran dapat diakses dan relevan untuk semua siswa.
4. P (Professional Educator):

Model Flipped Classroom seringkali lebih menuntut peran guru secara profesional. Selama di kelas, guru terus mengamati siswa, memberikan umpan balik secara langsung, dan menilai hasil pekerjaan siswa. Sesama guru saling terhubung untuk meningkatkan kualitas pengajaran, menerima kritik atau masukan yang membangun, dan menoleransi kesalahan yang terjadi di dalam kelas. Guru secara profesional mengambil peran yang kurang menonjol di dalam kelas, tetapi tetap menjadi unsur penting agar model Flipped Classroom terlaksana dengan baik. Flipped Learning Network (2014) menyebutkan ada tiga indikator yang digunakan:

a. Guru menyediakan waktu untuk memberikan umpan balik kepada siswa, baik secara individu, kelompok kecil maupun keseluruhan siswa di dalam kelas.

b. Guru melakukan penilaian formatif berkelanjutan selama waktu pembelajaran di kelas melalui observasi dan dengan merekam data agar memperoleh informasi untuk merancang pembelajaran berikutnya.

c. Guru berkolaborasi dan melakukan refleksi dengan rekan guru yang lain serta bertanggung jawab dalam praktik mengajar di kelas.

\section{Kelebihan dan Kekurangan Flipped Classroom}

Meskipun muncul bermacam-macam model pembelajaran, dapat dipahami bahwa tidak ada satu pun model pembelajaran yang sempurna. Artinya, selain memiliki kelebihan, tentunya model-model pembelajaran tersebut memiliki kekurangan, begitu juga dengan model Flipped Classroom. Berdasarkan hasil analisis bibliometri yang dilakukan oleh Çakýr, dkk. (2021) dalam rentang waktu antara tahun 2015-2019, secara umum menunjukkan kelebihan dan kelemahan dari penggunaan model Flipped Classrom.

\section{Kelebihan:}

1. Siswa lebih aktif dalam memahami materi pelajaran.

2. Siswa lebih siap berada di kelas karena 
Mujiono: Flipped Classroom. Sekolah Tanpa Pekerjaan Rumah

selama di rumah sudah belajar materi pelajaran (pra-pembelajaran).

3. Memberikan pembelajaran permanen karena memiliki kesempatan untuk mengulang materi pelajaran sebanyak yang diinginkan.

4. Memotivasi siswa dengan memberikan perhatian lebih kepada mereka.

5. Memberikan kesempatan kepada siswa agar mudah menyiapkan konten pembelajaran.

6. Siswa belajar dengan kecepatan mereka sendiri dan mengambil tanggung jawab belajar masing-masing.

7. Waktu dapat digunakan dengan lebih efisien dan kreatif.

8. Memungkinkan siswa untuk mengakses materi pelajaran dari rumah masingmasing, seandainya mereka berhalangan hadir di kelas.

\section{Kekurangan:}

1. Ketersediaan jaringan internet yang dimiliki siswa mempengaruhi akses ke konten pembelajaran.

2. Menimbulkan masalah bagi siswa yang tidak dapat memotivasi diri mereka sendiri untuk belajar karena mereka belajar dengan kecepatan mereka sendiri.

3. Harapan siswa bisa belajar dalam waktu singkat dapat berdampak buruk pada kualitas pembelajaran.

4. Kondisi siswa ketika melakukan pembelajaran di luar kelas tidak dapat dikontrol.

5. Ketidakmampuan guru menyiapkan konten video menjadi masalah.

6. Kondisi negatif ketika video berdurasi panjang dan masalah teknis mungkin ditemui saat siswa menonton video.

\section{SIMPULAN DAN SARAN}

\section{Simpulan}

Penggunaan model pembelajaran Flipped Classroom memberikan keuntungan, baik bagi guru maupun siswa. Kapasitas waktu belajar yang disediakan oleh model pembelajaran Flipped Classroom mampu mengakomodasi beragam siswa dengan kemampuan dan kecepatan belajar yang berbeda-beda. Guru menyediakan bahan/ konten pembelajaran untuk siswa sesuai dengan materi pelajaran dan tujuan pembelajaran yang telah ditentukan. Pemanfaatan bahan belajar yang tersebar di internet akan mempermudah guru-guru yang tidak bisa memproduksi sendiri bahan belajar untuk siswa. Misalnya, dalam situs Rumah Belajar yang dikembangkan oleh Kemendikbud, terdapat berbagai bahan belajar yang tersedia dalam berbagai format. Guru dapat memanfaatkan bahan belajar untuk siswa dengan format yang beragam, menyesuaikan dengan gaya belajar siswa. Selama di kelas, guru membimbing siswa untuk memahami materi pelajaran yang belum dimengerti.

Kegiatan kolaboratif terjadi tidak hanya antara guru dengan siswa, melainkan juga antarsiswa dalam satu kelompok. Banyak keuntungan yang diperoleh dari kolaborasi antarsiswa dalam kelompok. Siswa menjadi lebih perhatian kepada teman-temannya dan lebih terbuka ketika menyampaikan pendapat selama diskusi dalam kelompok. Selain memperoleh keuntungan akademik, kegiatan kolaboratif juga memberikan keuntungan sosial. Persahabatan antarsiswa akan terjalin lebih erat karena mereka akan terbiasa bekerjasama.

\section{Saran}

Tuntutan zaman semakin ke depan semakin berat. Tidak cukup bila hanya mengandalkan kemampuan menghafal saja. Siswa perlu diajarkan kemampuan berpikir tingkat tinggi, sehingga mereka nantinya mampu menyelesaikan masalah dalam pekerjaan dan kehidupannya. Guru-guru di sekolah diharapkan mulai berpikir ulang serta melakukan refleksi tentang cara mengajar mereka. Perbedaan karakteristik dan kemampuan siswa yang berkaitan dengan cepat atau lambatnya dalam memahami materi pelajaran tertentu perlu diperhatikan, agar tujuan pembelajaran dapat tercapai sesuai dengan yang diharapkan. Guru-guru harus kreatif dalam mengelola pembelajaran dan berani mencoba mengembangkan dan 
Mujiono: Flipped Classroom. Sekolah Tanpa Pekerjaan Rumah

menerapkan model-model pembelajaran inovatif, yaitu model-model pembelajaran yang berorientasi kepada siswa sebagai pusat pembelajaran, sehingga memberikan peluang kepada siswa untuk bisa mengembangkan kemampuan dan potensi yang dimilikinya.

\section{PUSTAKA ACUAN}

Akýn, E. (2016). Flipped classroom learning model and its availability in Turkish education.

Arnold-Garza, S. (2014). The flipped classroom teaching model and its use for information literacy instruction. Communications in Information Literacy, 8(1), 9.

Bassett, S., Bowler, M., \& Newton, A. (2013). Schemes of work, units of work and lesson planning. Learning to Teach in the Secondary School: A Companion to School Experience, 65-76.

Bergmann, J., \& Sams, A. (2012). Flip your classroom: Reach every student in every class every day. International society for technology in education.

Black, A., Lawson, H., \& Norwich, B. (2019). Lesson planning for diversity. Journal of Research in Special Educational Needs, 19(2), 115-125.

Breimer, E., Fryling, M., \& Yoder, R. (2016). Full flip, half flip and no flip: Evaluation of flipping an introductory programming course. Information Systems Education Journal, 14(5), 4.

Çakir, R., Sayin, V., \& Bektas, S. (2021). Bibliometric Analysis of Studies Conducted between 2015-2019 on the Flipped Classroom Model. International Journal of Research in Education and Science, 7(1), 163-187.

Cevikbas, M., \& Argün, Z. (2017). An innovative learning model in digital age: Flipped classroom. Journal of Education and Training Studies, 5(11), 189-200.

Darmadi, H. (2017). Pengembangan model dan metode pembelajaran dalam dinamika belajar siswa. In Yogyakarta: Deepublish.

Darmawan, D., \& Harahap, E. (2016). Communication strategy for enhancing quality of graduates nonformal education through computer based test (CBT) in West Java
Indonesia. 11, 8641-8645.

Darmawan, D., Ruyadi, Y., Abdu, W. J., \& Hufad, A. (2017). Efforts to Know the Rate at which Students Analyze and Synthesize Information in Science and Social Science Disciplines: A Multidisciplinary Bio-Communication Study. OnLine Journal of Biological Sciences, 17(3), 226-231.

Drisko, J. W., \& Maschi, T. (2016). Content analysis. Pocket Guides to Social Work R.

Eppard, J., \& Rochdi, A. (2017). A Framework for Flipped Learning. International Association for Development of the Information Society.

Fisher, R., Ross, B., LaFerriere, R., \& Maritz, A. (2017). Flipped learning, flipped satisfaction, getting the balance right. Teaching \& Learning Inquiry, 5(2), 114-127.

Gomez-Lanier, L. (2018). Building Collaboration in the Flipped Classroom: A Case Study. International Journal for the Scholarship of Teaching and Learning, 12(2), 7.

Hubbell, E. R., \& Goodwin, B. (2019). Instructional Models: Doing the Right Things Right. MCREL International.

Isrok'atun, I. (2016). Model Pembelajaran Matematika Situation-Based Learning di Sekolah Dasar. UPI Sumedang Press.

Jarir, J., \& Khairiah, K. (2019). NILAI-NILAI DAKWAH DI MEDIA MASSA (KAJIAN TERHADAP RUBRIK OPINI RIAU POS). Al Imam: Jurnal Manajemen Dakwah, 182-194.

Krahenbuhl, K. S. (2017). An Engaging, yet Failed Flip. InSight: A Journal of Scholarly Teaching, 12, 132-144.

Krippendorff, K. (2018). Content analysis: An introduction to its methodology. Sage publications.

Kurihara, Y. (2016). Flipped classroom: Effects on education for the case of economics. Journal of Education and E-Learning Research, 3(2), 65-71.

Lorin, W. A., \& David, R. . (2015). Kerangka Landasan untuk Pembelajaran, Pengajaran Dan Asesmen. Yogyakarta: Pustaka Pelajar.

Mazur, A., Brown, B., \& Jacobsen, M. (2015). Learning Designs using Flipped Classroom Instruction| Conception d'apprentissage à l'aide de l'instruction en classe inversée. Canadian Journal of Learning and Technology/ 
Mujiono: Flipped Classroom. Sekolah Tanpa Pekerjaan Rumah

La Revue Canadienne de l'apprentissage et de La Technologie, 41(2).

McCollum, B. M., Fleming, C. L., Plotnikoff, K. M., \& Skagen, D. N. (2017). Relationships in the Flipped Classroom. Canadian Journal for the Scholarship of Teaching and Learning, 8(3), p.n3.

Millard, E. (2014). 5 Reasons Why Flipped Classrooms Work. Embracing New Paradigms in Education, compiled by HW Wilson. 224228.

Mujiono. (2017a). Bahan Belajar Mandiri Mata Pelajaran Desain Grafis menggunakan Media Video untuk Siswa Tunarungu. Prosiding Lomba Karya Tulis IImiah Guru SMA/Sederajat Dan Dosen Se-Jawa Timur Tahun 2017, 4651.

Mujiono. (2017b). Pengembangan E-learning Sebagai Pusat Sumber Belajar untuk Mendukung Student Centered Learning. Seminar Nasional Teknologi Pembelajaran Dan Pendidikan Dasar 2017, 49-55.

Mujiono, M., Degeng, I. N. S., \& Praherdhiono, H. (2018). Pengembangan Pembelajaran Sistem Blended Berbasis Universal Design for Learning untuk Kelas Inklusif. Jurnal Pendidikan: Teori, Penelitian, Dan Pengembangan, 3(6), 758-763.

Nadia, Z., \& Hadi, S. (2015). Pengaruh model pembelajaran guided inquiry terhadap hasil belajar IPA. Jurnal Teknodik, 141-155.

Network, F. L. (n.d.). FLN,(2014). The Four Pillars of FLIPTM. Recuperado de: Http:// Flippedlearning. Org/Cms/Lib07/VA01923112/ Centricity/Domain/46/FLIP_handout_ FNL_Web. Pdf.

Osman, S. Z. M., Jamaludin, R., \& Iranmanesh, M. (2015). Student Centered Learning at USM: What Lecturer and Students Think of This New Approach?. Journal of Education and Practice, 6(19), 264-277.

Ozdamli, F., \& Asiksoy, G. (2016). Flipped Classroom Approach. World Journal on Educational Technology: Current Issues, 8(2), 98-105.
Pinnelli, S., \& Fiorucci, A. (2015). University and Flipped Learning TIC \& DIL Project: Framework and Design. International Association for Development of the Information Society.

Rahayu, W. (2015). Model Pembelajaran Komeks: Bermuatan Nilai-Nilai Pendidikan Karakter Aspek Membaca Intensif di SD. Deepublish.

Rhim, L. M. (2020). A good school is good for students of all abilities. Phi Delta Kappan, 102(3), 18-22.

Sani, R. A. (2013). Inovasi pembelajaran. In Jakarta: Bumi Aksara.

Schmidt, S. M. P., \& Ralph, D. L. (2016). The flipped classroom: A twist on teaching. Contemporary Issues in Education Research (CIER), 9(1), 1-6.

Slavin, R. E. (2011). Psikologi pendidikan teori dan praktik. In Jakarta: indeks.

Smith, V. D., \& Darvas, J. W. (2017). Encouraging Student Autonomy through Higher Order Thinking Skills. Journal of Instructional Research, 6, 29-34.

Suo, J., \& Hou, X. (2017). A study on the motivational strategies in college English flipped classroom. English Language Teaching, 10(5), 62-67.

Warsihna, J. (2013). Model Pembelajaran Dengan TIK Di Sekolah Kategori Perintis. Jurnal Teknodik, 446-455.

Widiana, I. W., \& Jampel, I. N. (2016). Learning Model and Form of Assesment toward the Inferensial Statistical Achievement by Controlling Numeric Thinking Skills. International Journal of Evaluation and Research in Education, 5(2), 135-147.

Zainuddin, Z., \& Halili, S. H. (2016). Flipped classroom research and trends from different fields of study. International Review of Research in Open and Distributed Learning, $17(3)$.

Zeki, C. P., \& Güneyli, A. (2014). Student teachers' perceptions about their experiences in a student centered course. South African Journal of Education, 34(3). 